\title{
Uşak İli Banaz İlçesinde Konut Mutfağında Kullanılan Tezgâh Malzemelerine Yönelik Kullanıcı Tercihleri Üzerine Bir Araştırma
}

\author{
Abdurrahman Karaman ${ }^{a *}$, Ali Naci Tankut ${ }^{\mathrm{b}}$, Mehmet Nuri Yıldırımc, \\ aUşak Üniversitesi, Banaz Meslek Yüksekokulu, Uşak. \\ ${ }^{b}$ Bartın Üniversitesi, Orman Fakültesi, Bartm. \\ cKarabük Üniversitesi, Safranbolu Meslek Yüksekokulu, Karabük.
}

\begin{abstract}
$\ddot{O} z$
Bu çalışmada, Uşak ili Banaz ilçesinin kentsel yerleşim alanın oluşturan farklı sosyoekonomik ve kültürel düzeylere sahip ailelerin (Alt/Orta/Üst/SED) mutfakları örnekleme tesadüfi yöntemiyle 196 adet seçilmiş olup, mutfak sabit donatı elemanlarından biri olan mutfak tezgâh malzeme çeşitlerinin tespitini yaparak bu çeşitliliğe bağh olarak tercih sebepleri araştırılmıştır. Bu çalısmada veriler, yüz-yüze anket uygulama şeklinde elde edilmiştir. Sonuçlara göre; ailelerin mutfak tezgâh malzemesinin kullanım yaygınlığı bakımından incelendiğinde en çok granit, mermer ve mermerit, en az ise laminant kaplama, werzalit, diğer, seramik, kuvars esash taş ve akrilik esash taş malzemesini tercih ettikleri görülmektedir. Tezgâh malzemelerinden laminat kaplama, werzalit, mermer, kuvars esash taş, mermerit ve seramiğin ekonomik olması: werzalit ve kuvars esaslı taşın ekolojik (çevreyle ilgili) olması: kuvars esasl taş, akrilik esash taş, seramik, mermer, granit ve mermeritin kimyasal maddelere karşı dayanıkl olması: kuvars esasl taş, werzalit, akrilik esash taş, mermerit ve granitin mekaniksel (darbe, aşınma ve çizilmeye vb) etkilere karşı dayanıkh olması: akrilik esash taş, kuvars esash taş, werzalit, granit ve mermeritin fiziksel (su alma, rutubet, sıcaklı̆ga vb) etkilere karşı dayanıkl olması nedeniyle tercih ettikleri görülmektedir.
\end{abstract}

Anahtar Kelimeler: Mutfak Tezgâhı, Tezgâh Malzemesi, Tüketici.

\section{A Study on User Preferences Towards Lathe Materials Used in the Kitchen of Housing of Usak Province of Banaz District}

\begin{abstract}
In this study, Uşak Banaz district of families with different socio-economic and cultural levels constitute the urban areas (lower / middle / upper / SED) cuisine is selected pieces 196 by the sampling random method, making the determination of the kitchen table kind of material, one of the kitchen fixed equipment elements connected to this diversity as to why the choice was investigated. In this study, the datas were obtained in the form of face-to-face survey. Families are examined in terms of prevalence of use of the kitchen counter top materials and according to the result, it seems that families prefer materials as marble mostly and the laminate coating, werzalite, acrylic, the quartz-based stone and ceramic materials. Least. These materials are seems to be prefered because marble, quartz-based stone, marble and wood and werzalite and quartz-based stone circle is related quartz-based stone, acrylic stone, ceramic, marble and is resistant to mermerit the substance: quartz based stones, werzalite, acrylic stone, cultured marble and granite mechanical (impact, abrasion and etc. scratch) is resistant to the effects of: acrylic stone, quartz
\end{abstract}


based stones, werzalite, granite and marble and wood physical (water absorption, humidity, temperature, etc.) against impact resistant.

Keywords: Kitchen Counter, Counter Materials, Consumer.

\section{Gíriş}

Aile bireylerin gün boyunca en fazla zamanını geçirdiği ve yoğun çalıştığı mekândır. Ayrıca günümüzde zaman kavramının insan hayatında gittikçe daha fazla önem kazanması da muıtfağın işlevselliğinin insan hayatındaki önemini daha da artırmaktadır.

Mutfakta üç ana tezgah vardır; pişirici ile evye arasındaki tezgah (hazırlama eylemi için), pişirme biriminin diğer tarafındaki tezgah (daha çok servise hazırlık ve servis amaçlı) ve evyenin diğer yanındaki tezgahdır (bulaşık yıkama ve temizleme amaçl1)

Yer dolapları üzerine monte edilen çalışma tezgâhları, üzerinde yemek hazırlıklarının yapıldığı, pişirme araçlarından indirilen sıcak tabanlı tencerelerin konulduğu, çeşitli kesici aletlere maruz kalan önemli bir çalışma bölgesidir. Tezgâhlar üzerinde gerçekleştirilen eylemler dikkate alındığında çizilme, aşınma, lekelenme gibi etkilere maruz kaldığından tezgâh üstü malzemelerin seçiminde dayanıklılığa göre performans kriterleri önem kazanmaktadır (Yıldırım, 1999).

Bir mutfak tasarımında kullanıcının fizyolojik-psikolojik ihtiyaçları ve alışkanlıklarının yanında, kullanıcı memnuniyeti ve kullanılan malzemelerin özellikleri de önem verilmesi gereken konular arasındadır. Bir mutfak mekânındaki sabit donatı elemanlarında kullanılan malzemelerin özellikleri kullanıcının konforu açısından önemlidir. Bu sabit donatı elemanlarından biri olan tezgâh, mutfakta yer alan eylemlerin birçoğunda etkin olarak kullanılmaktadır. Buna bağlı olarak yanlış malzeme seçiminden doğan kullanım zorluğu ve ortaya çıkan zaman kaybı, kullanıcının aleyhine yaşanan bir durumdur. Ayrıca seçilen malzemenin kalitesi, malzeme ömrünü etkileyen bir faktördür. Tezgâh malzemelerin ekonomik ve ekolojik olması, ayrıca kimyasal maddelere karşı dayanımı, mekaniksel ve fiziksel etkilere karşı dayanımı kullanışlılığını belirleyen unsurlardır.

Uşak ili Banaz ilçe merkezinde yaşayan farklı sosyo-ekonomik-ve kültürel (Alt/Orta/Üst SED) düzeylere sahip tüketiciler çalışma evrenini oluşturmaktadır. Anketler her haneden bir kişiye yapıldığından dolayı ana kütle Banaz ilçe merkezindeki konut sayılarına göre belirlenmiştir.

Konut mutfak tezgahlarında da diğer donatı elemanları gibi yeni ürünler geliştirilmiştir. Günümüz modern mutfak tezgahlarında bu ürünler kullanılmaya başlanmıştır. Bu araştırma Uşak İli Banaz ilçe sınırları içersinde, farklı statülerdeki sosyo-ekonomik özelliklere (cinsiyet, yaş, öğrenim durumu, medeni durum, meslek, aylık gelir, mülkiyet durumu ve konut yaşı), kullanıcıların mutfak tezgahında kullandıkları malzemelerin belirlenmesi ve tercih etmedeki kriterleri belirlemek amacıyla yapılmıştır. 


\section{LITERATÜR TARAMASI}

İnsanların yaşam tarzının değişmesi konutların yeniden biçimlenmesine neden olmuştur. Günümüzde hızla gelişen yaşam düzeyine, değişen teknolojik ve ekonomik koşullara karşın konutlardan, içlerinde yaşayan insanların fiziksel ve fizyolojik ihtiyaçlarına cevap vermesi beklenirken; daha ekonomik olmaları sebebiyle bazı gereksinmelerin karşılanmasından ödün verilmektedir. Mutfak mekânında, kullanıcı tercihleri doğrultusunda istenilen detayların irdelenmesi, kullanıcıyı rahatsız edici noktaların belirtilmesi, estetik ve fonksiyonel tasarımlar için gerekli kriterleri araştırmıştır (Efendioğlu, 2001).

Konut mutfaklarına yönelik olarak yürütülen çok sayıda çalışma yapılmıştır. Bunlardan; İmamoğlu (1986), Ankara'da üç sosyo-ekonomik düzey (SED) konutlarında yaptığı araştırma sonucunda; OSED ailelerinin fiziki koşulları ve yaşam biçimlerinin ASED ailelerinden çok ÜSED ailelerine benzerlik gösterdiğini belirtmiştir. Kalınkara (1990), Ankara'nın çeşitli semtlerinde bulunan orta sosyo-ekonomik duruma sahip 60-74 yaş grubuna giren kadınların mutfaklarında çalışma merkezine bağlı olarak çalışma yükseklikleri ve kadınların antropometrik ölçüleri üzerine araştırma yapmıştır. Sözer (1990), Konut mutfaklarındaki kullanıcıların gereksinimlerine bağlı olarak, boyutsal düzenleme faktörü olan ergonomik ve antropometrik yaklaşımlar, mutfak tasarımında modüler koordinasyon ve mutfağ tasarımının da önemli bir yer tutan fiziksel çevre koşulları ile malzeme ve renk faktörü gibi donatı elemanlarının planlaması gerektiğini belirtmiştir. Işık (1992), Çeşitli sosyo-ekonomik düzey ailelerinin konut kullanımını, yaşam biçimini, iç mekân düzenlemelerini, eşyanın nicelik ve nitelikleri ile depolama sorunlarını inceleyerek; OSED ve ÜSED konutlarının büyüklüğü, donatı elemanlarını düzenlenişi ve yaşam biçimleri arasında bir benzerlik olduğunu belirtmiştir. Zorlu (1996), Mutfak mekânının konut içindeki yeri ve önemine bağlı olarak kullanıcının ihtiyaçları çerçevesinde planlanması gerektiğini belirtmiştir. Yıldırım (1999), Ankara'da farklı sosyo-ekonomik düzeyine sahip ailelerin (Alt/Orta/Üst SDE) mutfakları üzerin bir araştırma yapmıştır. İlçe (2001), Ankara ve Tokat illerinde bulunan farklı sosyo-kültürel yapıya ve ekonomik koşullara sahip bireylerin fizyolojik ve psikolojik etkenlerin çerçevesinde mutfak tasarımına etkilerini açıklamıştır. Yeşilkavak (2006), Ankara'da bulunan orta sosyo-ekonomik düzeye sahip kullanıcıların mutfak mekânını algılama şekilleri üzerine bir çalışma yapmıştır. Küreli (1996), Islak mekânlar için tabakalı malzeme olarak lif levhanın, üst yüzey gereci olarak iki bileşenli poliüretan verniğin uygun olduğunu belirtmiştir.

Mutfak tezgâhlarında doğal taşlar, masif ağaç ve ağaç türevi malzemeler, seramik, çelik gibi geleneksel malzemelerin yanında son zamanlarda mekanik, fiziksel ve kimyasal etkiler karşısında direnci yüksek ve dekoratif görünüşlü sentetik malzemeler kullanılmaktadır (Söğütlü, 1998)

Mutfak tezgâhlarında kullanılan malzemelerden Werzalit, laminat (HPL), vernikli ve verniksiz lif levha ve doğu kayının mekanik etkilere karşı performansını karşılaştırarak, en yüksek aşınma direncini poliüretan vernik ile kaplanmış doğu 
kayınında, en yüksek çizilme direnci, brinell sertlik ve pandüllü sertlik değerlerini werzalit’ te elde etmiştir (Söğütlü, 1998).

Delaloğlu (2002), Mutfak mekânı içinde bulanan sabit donatı elemanlarından en sık kullanılan tezgâh bölümünün fiziksel, kimyasal ve mekanik etkilere karşı dayanımını incelemiştir. Mutfak mekânı içinde bulanan sabit donatı elemanlarından en sık kullanılan mutfak tezgâh sıralamasının; laminant tezgâh, mermerit, mermer, polikor ve granit şekilde olduğunu belirtmiştir.

Elde edilen veriler sonucunda kullanım memnuniyetleri ve şikâyetlere bağlı olarak ilgili birimler tarafından mutfak tezgâhı olarak, aşınma payı çok düşük, leke tutmayan, kolay temizlenebilen, 1sı ve darbe gibi fiziksel etkilerden ve kimyasal maddelerden etkilenmeyen, bütün olarak üretilebilen bir tezgâh malzemesi üretimi gerçekleştirmenin yararlı olabileceğini belirtmiştir. Bir mutfak tasarımında kullanıcının fizyolojik-psikolojik ihtiyaçları ve alışkanlıklarının yanında, kullanıcı memnuniyeti ve kullanılan malzemelerin kimyasal, mekanik ve fiziksel özelliklerine de önem verilmesi gereken konular olduğunu belirtmiştir. (Tavşan ve Küiçük, 2013).

\section{Mutfak Tezgâhında Kullanılan Malzemeler ve Özellikleri}

Kesme, doğrama yıkama gibi çeşitli eylemlerin üzerinde gerçekleştiği mutfak tezgâh malzemeleri kullanıcı ihtiyaçlarına bağlı olarak farklılık göstermektedir. Mutfak tezgâh malzemelerini şöyle sıralamak mümkündür:

\section{Mermer}

Billurlaşmış kireç taşlarının yüksek sıcaklık, basınç ve kesme kuvveti etkisi altında değişikliğe uğraması sonucunda oluşan renkli ya da beyaz, damarlı ya da damarsız çeşitleri bulunan bir çeşit kireç taşıdır (Hasol, 2002). Yumuşak bir yapıya sahip olması nedeniyle uzun ömürlü bir malzeme değildir. Asitlere karşı dayanıksızdır ve kolay çizilebilen bir özelliğe sahiptir (Anonim, 2007a).

\section{Granit}

Kuvars, alkali feldspat, ortoklaz ve mika minerallerinden birleşmiş türlü renkte, billursu ve çok sert bir tür kayaçtır. Kalın dilimler halinde kesilerek tezgâh olarak monte edilirler. Kaplamaların montajında el becerisi ve işçilik önem arz eder. Isıyı izole eder, çizilmez, uzun ömürlü ve dayanıklıdır. Yüzeyine periyodik olarak cila işlemi yapılması gerekir. Leke tutan ve çatlayabilen bir malzemedir (Hasol, 2002; Anonim, 2007a; Anonim, 2007b; URL-2, 2013).

\section{Laminant}

İç tabakaları fenolik reçine, üst tabakası melamin formaldehitle doyurulmuş, $170^{\circ}$ C sicaklıkta $100-120 \mathrm{~kg} / \mathrm{cm}^{2 \prime}$ lik basınç uygulanarak ve $60-90$ dakika süre ile preslenerek tek veya iki yüzeyi üzerine dekoratif renk ve desen oluşturabilen lifli levhalardır. Doku, renk, tasarım ve estetik açıdan geniş olanaklar sunar (Nemli, 2000). 


\section{Kuvars esaslı taş}

Billurlaşmış silis olarak tanımlanan kuvarsın parçacıklar halinde bir araya gelmesi ile oluşan bir malzemedir (Hasol, 2002). Sıvı emmeyen bir yapıya sahiptir; asit ve bazlardan etkilenmemektedir. Hijyeniktir ve çizilmeyen bir yapıya sahiptir (URL-4, 2013).

\section{Akrilik esaslı taş}

Döküm tekniği kullanılarak \%100 akrilik esaslı ya da 1/3 oranında akrilik reçinesi, 2/3 oranında alüminyum trihidrat ve renk pigmentleri kullanılarak üretilmektedir. Ek yeri belli olmaksızın monte edilebilen, ebat sinırı bulunmayan, gözeneksiz bir malzemedir. Darbelere ve kimyasal maddelere karşı dayanıklıdır, hijyeniktir ve istenilen renkte oluşturulmaktadır. Kolay temizlenebilme ve kolay tamir edilebilme özelliğine de sahiptir (URL-5, 2013).

\section{Werzalit}

Kalıp preste biçimlendirilmiş ve kaplanmış yonga levha olarak da bilinen werzalit uygun yapıştırıcı maddelerle tutkallanmış olan yongaların, özel kalıp preslerde, sicaklık etkisi altında tek kademede biçimlendirilmesi ve uygun malzemeyle kaplanması sonucunda elde edilir. Werzalit, su ve rutubete dayanıklı olup, 1sıdan etkilenmez (Akgül, 2008).

\section{Mermerit}

Maden ocaklarında elde edilen kalsit, dolunut gibi beyaz taşların toz haline getirilip ufalanması ve polyester yapıştırıcının katılımı sonucu renk pigmentleriyle birlikte doldurularak katılaşmasından oluşan bir malzemedir. Donma işlemi mekparoksit ve kobalt sıvılarının katılımı ile hızlandırılır. Sert ve esnek bir malzeme olan mermerit. çatlama ve kırılmaya karşı dayanıklıdır. Homojen bir yapıya sahip olup, su ve havadan etkilenmez. Çizilmeye karşı hassas olup, $220 \mathrm{C}^{\prime}$ den fazla sıcaklığa maruz kalmaması gerekir. İstenilen ebat ve renklerde üretilme imkânı vardır (Akgül, 2008).

\section{Seramik}

Organik olmayan malzemelerin çeşitli yöntemlerle şekillendirilmesi, sırlanması ve pişirilmesi sonucu oluşan sert bir malzemedir. Temizlemesi kolay ve 1sıya karşı dayanıklıdır. Bütün olarak değil parçalar halinde bir yapıştırıcı malzeme ile monte edilir. Fayanslar kolay çizilebilir ya da çatlayabilir ayrıca dolgu kısımları zamanla leke tutabilir (URL-3, 2013).

\section{MATERYAL VE YÖNTEM}

Araştırmada birçok verinin elde edilebilmesi için anket (soru sorma tekniği kullanılmıştır. Hazırlanan anket formu demografik özellikler, mutfak tezgah malzeme çeşitleri ve bu malzemeye bağlı olarak tüketicilerin tercih etme sebeplerin yer aldığ 2 bölümden oluşmaktadır. Birinci bölümde 8 soruluk kişisel bilgiler (cinsiyet, yaş, öğrenim durumu, medeni durum, meslek, aylık gelir, mülkiyet durumu ve konut yaşı), 
ikinci bölümde ise Atılgan (2012), tarafından "Konut Mutfak Dolaplarında Tercih Edilen Kapak Modelleri: Artvin İli Örneği" adlı çalışmada kullanılan ailelerin mutfak tezgâh malzemelerini tercih etme sebepleri ile ilişkili olarak sorular sorulmuştur. Bu bölümde 20 maddeden oluşmakta ve 5 likert ölçeği kullanılmıştır (1: Hiç katılmıyorum, 2: Katılmiyorum, 3: Kismen Katıliyorum, 4: Katılıyorum, 5: Tamamen katılıyorum).

Uşak ili Banaz ilçe merkezinde yaşayan farklı sosyo-ekonomik-kültürel (Alt/Orta/Üst SED) düzeylere sahip tüketiciler çalışma evrenini oluşturmaktadır. Anketler her haneden bir kişiye yapıldığından dolayı ana kütle Banaz ilçe merkezindeki konut sayılarına göre belirlenmiştir. Banaz Belediyesi Su İşleri Müdürlüğünden edinilen veriler ile anakütle sayısının 8178 olduğu belirlenmiştir.

Örnek büyüklüğü aşağıdaki formüle göre belirlenmiştir (Gürleyen, 2005).

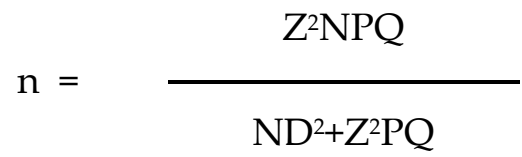

Burada;

n=Örnek büyüklüğpü

$\mathrm{Z}=$ Güven katsayısı (\%95 için 1,96 alınmıştır).

$\mathrm{P}=$ Ölçmek istediğimiz özelliğin toplumda bulunma ihtimali (\%97 olarak alınmıştır).

$\mathrm{Q}=1-\mathrm{P}$ (Ölçmek istenen özelliğin ana kütlede bulunmama ihtimali).

$\mathrm{N}=$ Ana kütle büyüklüğü.

$\mathrm{D}=$ Kabul edilen örnekleme hatası (Çalışma için \%3'lük örnekleme hatası öngörülmüştür).

Yukarıdaki formüle gore örnek büyüklüğü 82 bulunmuştur. Çalışmanın daha sağlıklı olması için bu sayı 196'ya çıkarılmıştır. Verilerin analizi SPSS 20.0 istatistik programıla yapılmıştır. Tüketicilerin anket formundaki sorulara verdikleri cevaplar veriler haline getirilerek frekans tabloları hazırlanmıştır. Grup sayısı 2 olan değişkenler için T testi, grup sayısı 2 den fazla olanlar için One Way Annova testi kullanılmıştır. 


\section{BULGULAR}

Ankete katılan tüketicilerin bazı demografik özellikleri Tablo 1'de verilmektedir.

Tablo 1. Ankete Katılan Tüketicilerin Bazı Demografik Özellikleri.

\begin{tabular}{|c|c|c|}
\hline Cinsiyet & $\mathrm{f}$ & $\%$ \\
\hline Erkek & 100 & 51,0 \\
\hline Kadın & 96 & 49,0 \\
\hline Yaş & f & $\%$ \\
\hline $18-24$ & 35 & 17,9 \\
\hline 25-34 & 61 & 31,1 \\
\hline $35-44$ & 59 & 30,1 \\
\hline $45-54$ & 34 & 17,3 \\
\hline 55 ve üzeri & 7 & 3,6 \\
\hline Eğitim Durumu & $\mathbf{f}$ & $\%$ \\
\hline Okur-Yazar Değil & 3 & 1,5 \\
\hline İlköğretim & 31 & 15,8 \\
\hline Lise & 38 & 19,4 \\
\hline Önlisans & 39 & 19,9 \\
\hline Lisans & 74 & 37,8 \\
\hline Yüksek Lisans & 9 & 4,6 \\
\hline Doktora & 2 & 1,0 \\
\hline Medeni Durumu & $\mathrm{f}$ & $\%$ \\
\hline Bekar & 52 & 26,5 \\
\hline Evli & 137 & 69,9 \\
\hline Dul & 7 & 3,6 \\
\hline Toplam Aylık Gelir Durumu & $\mathrm{f}$ & $\%$ \\
\hline 1300 TL den az & 50 & 25,5 \\
\hline $1301-2000 \mathrm{TL}$ & 42 & 21,4 \\
\hline $2001-2700 \mathrm{TL}$ & 31 & 15,8 \\
\hline 2701-3400 TL & 45 & 23,0 \\
\hline $3401-4100 \mathrm{TL}$ & 15 & 7,7 \\
\hline 4100 TL üzeri & 13 & 6,6 \\
\hline
\end{tabular}


Tablo 1. Ankete Katılan Tüketicilerin Bazı Demografik Özellikleri (Devamı)

\begin{tabular}{lccc}
\hline & Meslek & f & \% \\
\hline İşçi & 36 & 18,4 \\
\hline Memur & 88 & 44,9 \\
\hline Emekli & Mülkiyet Durumu & 6 & 3,1 \\
\hline Ev Hanımı & & 18 & 9,2 \\
\hline Esnaf & & 17 & 8,7 \\
\hline Diğer & Konut Yaşı & 31 & 15,8 \\
\hline Kendi Evim & & f & $\%$ \\
\hline Kirac1 & 121 & 61,7 \\
\hline & & 75 & 38,3 \\
\hline $0-5$ Yil & & f & $\%$ \\
\hline $5-10$ Yıl & 53 & 27,0 \\
\hline $10-15$ Yıl & & 50 & 25,5 \\
\hline 15 Yıl üstü & & 45 & 23,0 \\
\hline
\end{tabular}

Tablo 1'de görüldüğü gibi ankete katılan tüketicilerin \%51'i erkek, \%49'u kadındır. Ankete katılan tüketici grupların \%17,9'u 18-24 yaş grubu; \%31,1'i 25-34 yaş grubu; \%30,1'i 35-44 yaş grubu; \%17,3'ü 45-54 yaş grubu ve \%3,6's1 55 ve üzeri yaş grubunu teşkil etmektedir. Tüketicilerin eğitim seviyeleri incelendiğinde, \%1,5' ğu okur-yazar değil; \%15,8'i ilköğretim mezunu; \%19,4'ü lise mezunu; \%19,9'u ön lisans mezunu; \%37,8'i lisans; \%4,6's1 yüksek lisans ve \%1'i de doktora mezunudur. Tüketici grupların medeni durumu incelendiğinde \%26,5'u bekâr grubu; \%69,9'u evli grubu ve $\% 3,6$ 'sı dul grubunu teşkil etmektedir. Tüketicilerin toplam aylık geliri incelendiğinde $\% 62,7^{\prime} \operatorname{sinin} 2700 \mathrm{TL}$ den az olduğu görülmektedir. Ankete katılan tüketici grubun yaklaşık \%63,3'ünü işçi ve memur kesimi oluşturmaktadır. Tüketicilerin konut mülkiyet durumları incelendiğinde \%61,7'sinin ev sahibi; \%38,3'nün kiracı olduğu görülmektedir. Konut yaşı olarak değerlendirdiğimizde ise konutların \%75,5'i 15 yıl ve altındadır. Buna göre Banaz da ikamet eden tüketicilerin yeni binalarda oturduğu söylenebilir.

Ankete katılan ailelerin kullandıkları mutfak tezgâh malzemeleri ve \% oranları Tablo 2, grafiksel gösterimi ise Şekil 1'de verilmiştir. Buna göre; tezgâh malzemesi olarak \%44,4 oranında granit; \%27 oranında mermer; \%15,3 oranında memerit; \%3,6 oranında akrilik esasl taş; \%3,1 oranında kuvars esash taş; \%2,6 oranında seramik; \%2 oranında diğer malzeme; \%1,0 oranında laminant kaplama ve werzalit malzeme kullandıkları görülmektedir. 
Tablo 2. Mutfak Tezgâh Malzemeleri

\begin{tabular}{|c|c|c|c|c|c|}
\hline Tezgâh Malzemeleri & $\mathbf{f}$ & $(\%)$ & Tezgâh Malzemeleri & f & $(\%)$ \\
\hline 1 Mermer & 53 & 27,0 & Mermerit & 30 & 15,3 \\
\hline 2 Granit & 87 & 44,4 & Werzalit & 2 & 1,0 \\
\hline Laminat Kaplama & 2 & 1,0 & Seramik & 5 & 2,6 \\
\hline Kuvars Esaslı Taş & 6 & 3,1 & Diğer & 4 & 2,0 \\
\hline 5 Akrilik Esaslı Taş & 7 & 3,6 & Toplam & & 100 \\
\hline
\end{tabular}

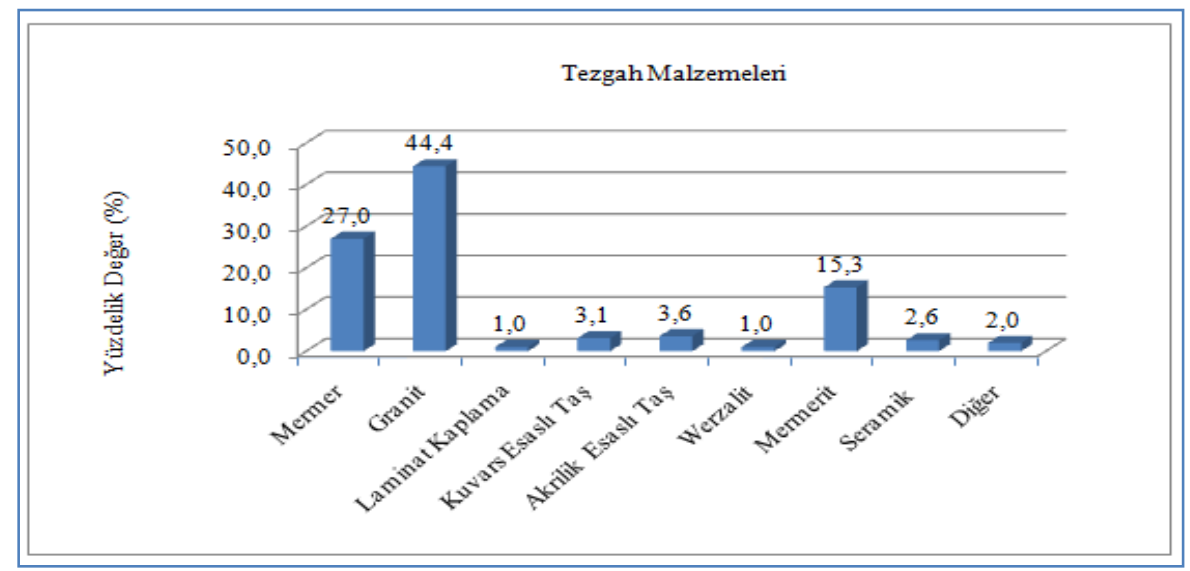

Şekil 1. Mutfak Tezgâhında Kullanılan lzemeler.

Ankete katılan ailelerin toplam aylık gelirine göre kullandıkları mutfak tezgâh malzemeleri ve \% oranları Tablo 3, grafiksel gösterimi ise Şekil 2'de verilmiştir

Tablo 3. Toplam Aylık Gelire Göre Mutfak Tezgâh Malzeme Dağılımı.

\begin{tabular}{|c|c|c|c|c|c|c|c|c|c|c|c|c|c|}
\hline \multirow{2}{*}{$\begin{array}{l}\text { Tezgah } \\
\text { Malzeme }\end{array}$} & \multicolumn{13}{|c|}{ Toplam Aylık Gelir (TL) } \\
\hline & G1 & $\%$ & G2 & $\%$ & G3 & $\%$ & G4 & $\%$ & G5 & $\%$ & G6 & $\%$ & Toplam \\
\hline Mermer & 23 & 43,4 & 12 & 22,6 & 6 & 11,3 & 8 & 15,1 & 1 & 1,9 & 3 & 5,7 & 53 \\
\hline Granit & 17 & 19,5 & 17 & 19,5 & 17 & 19,5 & 23 & 26,4 & 8 & 9,2 & 5 & 5,7 & 87 \\
\hline $\begin{array}{l}\text { Laminat } \\
\text { Kaplama }\end{array}$ & 0 & 0 & 1 & 50 & 1 & 50 & 0 & 0 & 0 & 0 & 0 & 0 & 2 \\
\hline $\begin{array}{l}\text { Kuvars } \\
\text { Esaslı } \\
\text { Taş }\end{array}$ & 2 & 33,3 & 2 & 33,3 & 0 & 0 & 1 & 16,7 & 1 & 16,7 & 0 & 0 & 6 \\
\hline
\end{tabular}

G1: 1300 den az, G2: 1301-2000, G3: 2001-2700, G4: 2701-3400, G5:3401-4000, G6:4101 ve üzeri. 
Tablo 3. Toplam Aylık Gelire Göre Mutfak Tezgâh Malzeme Dağılımı (Devamı)

\begin{tabular}{|c|c|c|c|c|c|c|c|c|c|c|c|c|c|}
\hline \multirow{2}{*}{$\begin{array}{l}\text { Tezgah } \\
\text { Malzeme }\end{array}$} & \multicolumn{13}{|c|}{ Toplam Aylık Gelir (TL) } \\
\hline & G1 & $\%$ & G2 & $\%$ & G3 & $\%$ & G4 & $\%$ & G5 & $\%$ & G6 & $\%$ & Toplam \\
\hline $\begin{array}{l}\text { Akrilik } \\
\text { Esaslı } \\
\text { Taş }\end{array}$ & 3 & 42,9 & 1 & 14,3 & 0 & 0 & 1 & 14,3 & 1 & 14,3 & 1 & 14,3 & 7 \\
\hline Werzalit & 1 & 50 & 1 & 50 & 0 & 0 & 0 & 0 & 0 & 0 & 0 & 0 & 2 \\
\hline Mermerit & 2 & 6,7 & 5 & 16,7 & 5 & 16,7 & 10 & 33,3 & 4 & 13,3 & 4 & 13,3 & 30 \\
\hline Seramik & 2 & 40 & 2 & 40 & 1 & 20 & 0 & 0 & 0 & 0 & 0 & 0 & 5 \\
\hline Diğer & 0 & 0 & 1 & 25 & 1 & 25 & 2 & 50 & 0 & 0 & 0 & 0 & 4 \\
\hline
\end{tabular}

G1: 1300 den az, G2: 1301-2000, G3: 2001-2700, G4: 2701-3400, G5:3401-4000, G6:4101 ve üzeri.

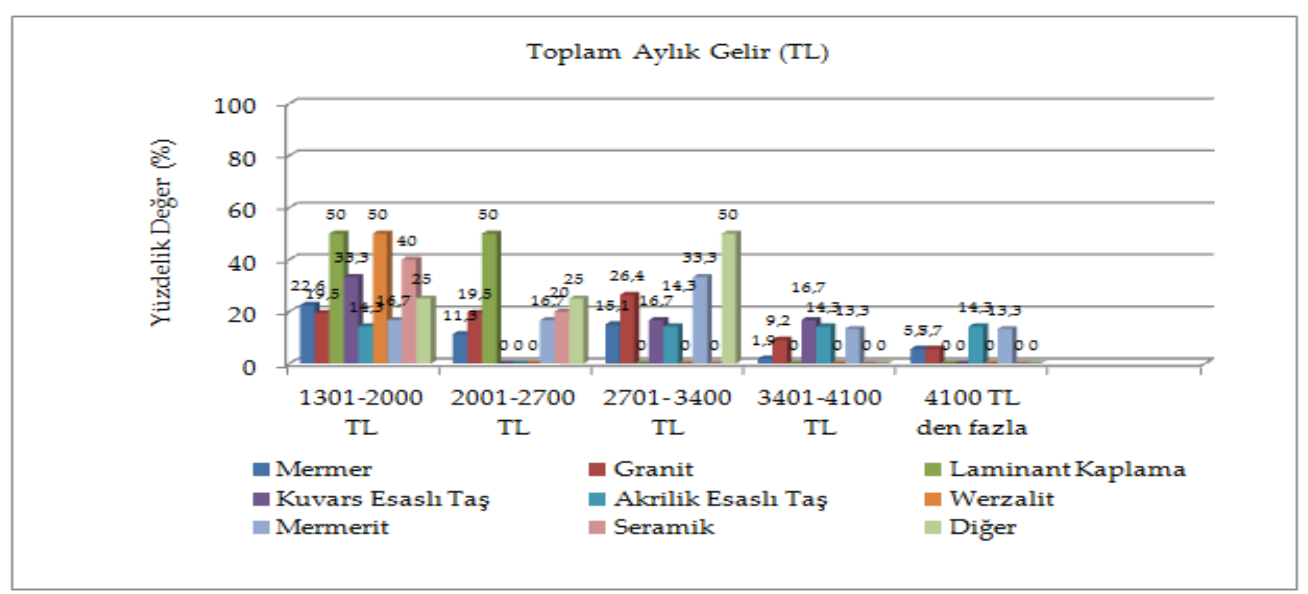

Şekil 2. Kullanıcıların Toplam Aylık Gelirine Göre Kullandıkları Mutfak Tezgâh

Malzemesi.

Şekil 2'e göre 1300 TL den az aylık gelire sahip olan kullanıcıların; werzalit, mermer, akrilik esaslı taş, seramik, kuvars esaslı taş; 1301- 2000 TL arasında toplam gelire sahip olanların laminant kaplama, werzalit, seramik ve kuvars esaslı taş; 2001-2700 TL arasında geliri olanların seramik, granit ve mermerit; 2701-3400 TL arasında geliri olanların mermerit ve granit; 3401-4100 TL arasında geliri olanların kuvars esaslı taş ve akrilik esaslı taş; 4101 TL ve üzeri geliri olanların akrilik esaslı taş ve mermerit malzeme kullanmaktadırlar.

Ankete katılan ailelerin oturdukları konut yaşlarına göre kullandıkları mutfak tezgâh malzemeleri ve \% oranları Tablo 4, grafiksel gösterimi ise Şekil 3'de verilmiştir. 
Tablo 4. Konut Yaşlarına Göre Mutfak Tezgâh Malzemelerin Dağılımı.

\begin{tabular}{lccccccccc}
\hline & \multicolumn{7}{c}{ Konut Yaşı (Yil) } \\
\cline { 2 - 9 } Tezgah Malzeme & $0-5$ & $\%$ & $5-10$ & $\%$ & $10-15$ & $\%$ & 15 Y 1 1 & $\%$ & Toplam \\
\hline Mermer & 12 & 22,6 & 10 & 18,9 & 14 & 26,4 & 17 & 32,1 & 53 \\
\hline Granit & 31 & 35,6 & 18 & 20,7 & 22 & 25,3 & 16 & 18,4 & 87 \\
\hline Laminat Kaplama & 0 &, 0 & 1 & 50 & 1 & 50 & 0 &, 0 & 2 \\
\hline Kuvars Esaslı Taş & 3 & 50 & 1 & 16,7 & 1 & 16,7 & 1 & 16,7 & 6 \\
\hline Akrilik Esaslı Taş & 1 & 14,3 & 3 & 42,9 & 2 & 28,6 & 1 & 14,3 & 7 \\
\hline Werzalit & 0 &, 0 & 1 & 50 & 0 &, 0 & 1 & 50 & 2 \\
\hline Mermerit & 4 & 14,3 & 14 & 46,7 & 5 & 16,7 & 7 & 23,3 & 30 \\
\hline Seramik & 0 &, 0 & 2 & 50 & 0 &, 0 & 3 & 60 & 5 \\
\hline Diğer & 2 & 50 & 0 &, 0 & 0 &, 0 & 2 & 50 & 4 \\
\hline
\end{tabular}

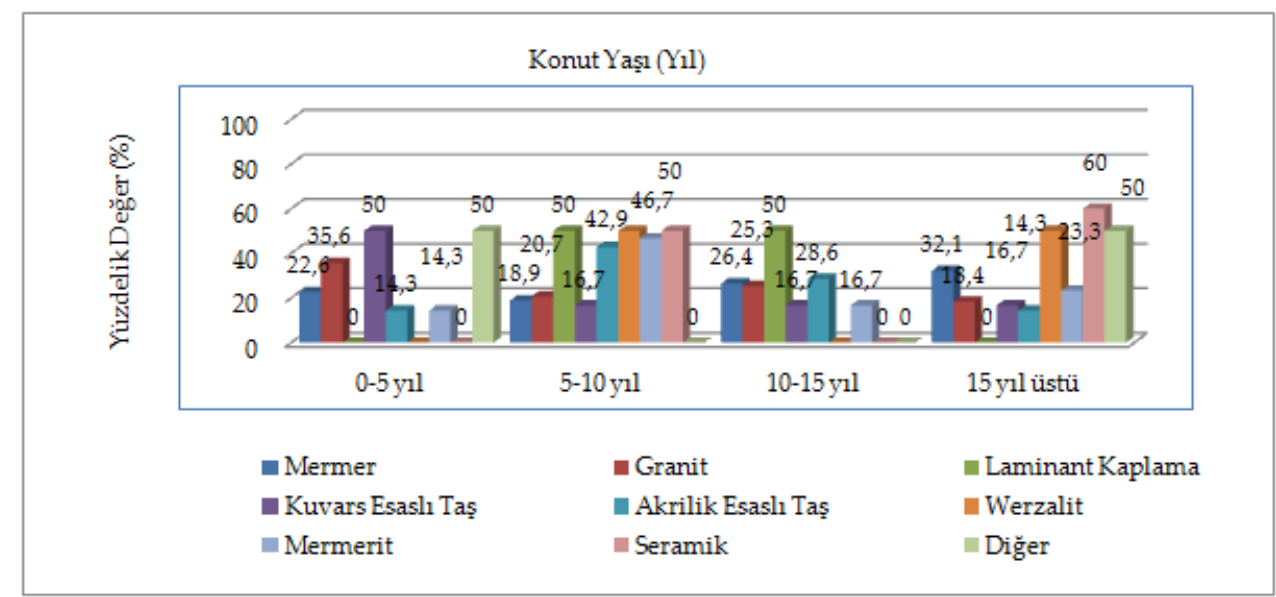

Şekil 3. Konut Yaşlarına Göre Mutfak Tezgâh Malzemelerin Dağılımı.

Şekil 3'de tüketicilerin oturdukları konut yaşlarına göre; konut yaşı 0-5 arasında olan kullanıcıların kuvars esaslı taş, granit ve mermer kullandıkları: konut yaşı 5-10 arsında olan kullanıcıların seramik, laminat kaplama, werzalit, mermerit ve akrilik esaslı taş kullandığı: konut yaşı 10-15 arasında olan kullanıcıların laminat kaplama, akrilik esaslı taş, mermer ve granit kullandığı: konut yaşı 15 yıl üstü olan kullanıcıların ise seramik, werzalit ve mermer kullanmaktadırlar. 


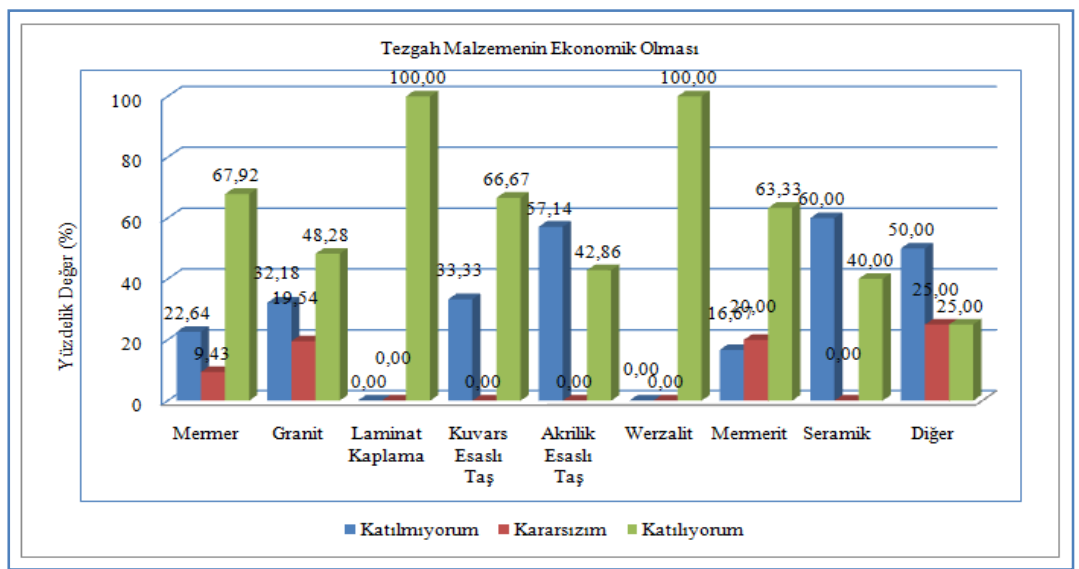

Şekil 4. Tezgâh Malzemesinin Ekonomik Olması Nedeniyle Tercih Edilmesi.

Yapılan araştırma sonucunda çeşitli tezgâh malzemeleri kullanan kullanıcıların memnuniyet dereceleri ölçülmüş̧tür (Şekil 4). Buna göre laminant kaplama, werzalit, mermer, kuvars esaslı taş ve mermerit kullanan kullanıcılar 'tezgahım ekonomik bir malzemedir' ibaresine katılmaktadırlar. Bu durumun tersine seramik ve akrilik esaslı taş kullanan kullanıcıların belirtilen ibareye katılmamaktadırlar.

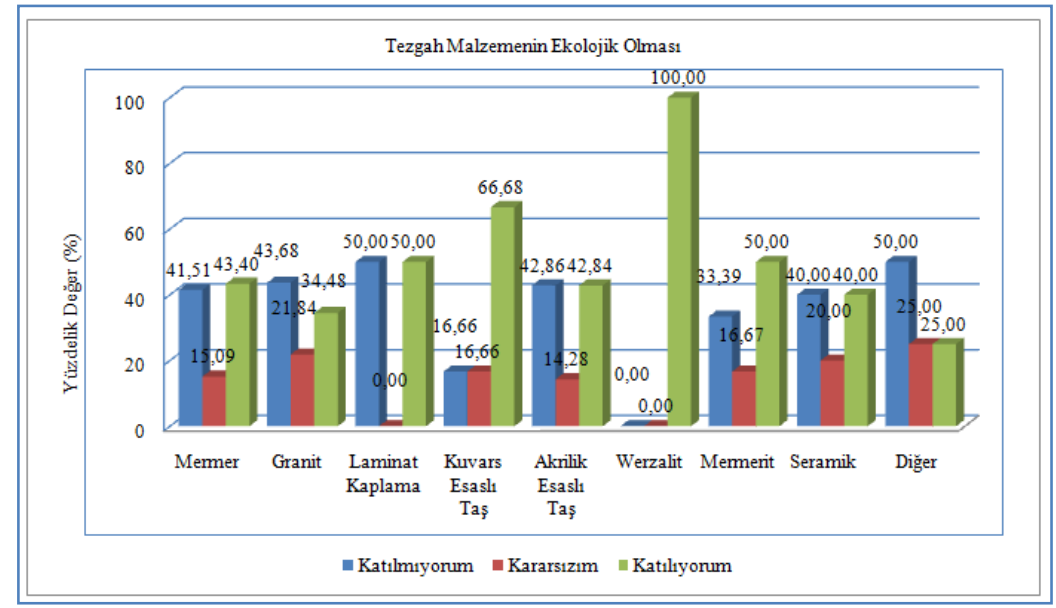

Şekil 5. Tezgâh Malzemesinin Ekolojik Olması Nedeniyle Tercih Edilmesi.

Ekolojik kelimesi endüstiriyelleşmenin etkilerinin yoğun bir şekilde hissedilmeye başlandığı yıllar ile birlikte dilimize yerleşen, kitle üretimlerinin bir sonucu olarak dünyaya verdiğimiz zararın farkındalığ1 ile önemini hissettiğimiz bir olgudur. Her geçen gün artan sera gazı etkisi ve buna bağlı olarak oluşan küresel ısınma, doğal kaynakların azalması gibi olaylar insanların doğa ile uyum içinde yaşamasını gerektiğini göstermektedir. İşte bu safhada ekolojik diğer adıyla çevre dostu ve ekonomik malzemeler devreye girmektedir. Bu doğrultuda Şekil 5'te kullanıcıların 'tezgahım ekolojik bir malzemedir' cümlesine katılıp katılmadıkları irdelenmiştir. Araştırma kapsamında tüketicilerde bu kavramın bilincinin kimi tüketici grubu tarafından oluştuğu gözlemlenmiştir. Buna göre werzalit kullanıcılarının tümü, werzalitin ekolojik bir malzeme olduğunu savunmakta; kuvars esaslı taş kullanıcılar ile laminant kaplama kullananlar bu ibareye katılmaktadır. Laminant kaplama 
kullananların yarısı ise kullandıkları malzemenin ekolojik bir malzeme olduğuna katılmamaktadir.

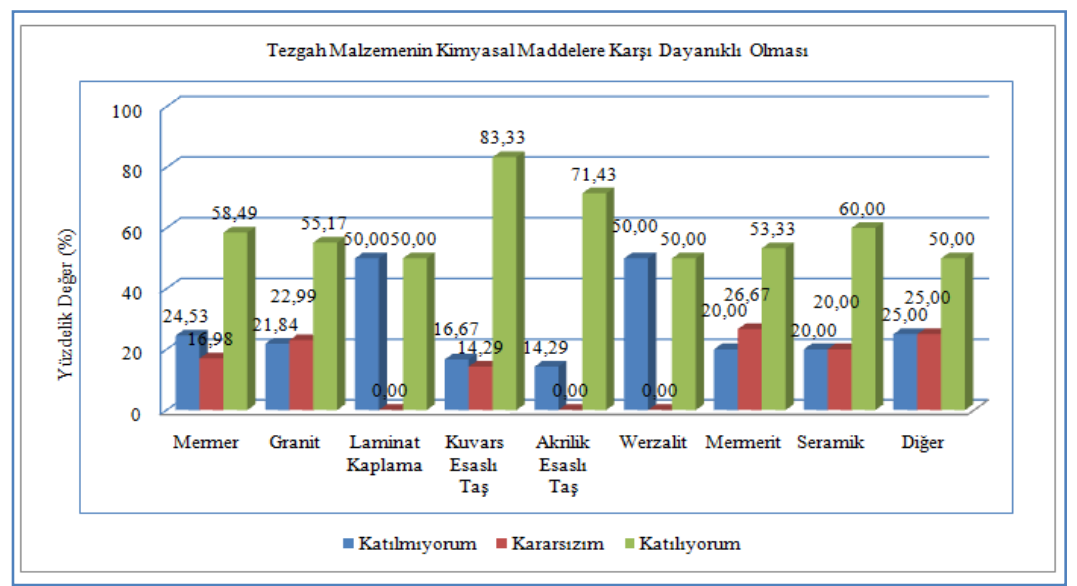

Şekil 6. Tezgâh Malzemesinin Kimyasal Maddelere Karşı Dayanıklı Olması Nedeniyle Tercih Edilmesi.

Yapılan araştırmaya göre kuvars esaslı taş, akrilik esaslı taş, seramik, granit, mermer ve mermerit kullanan kullanıcıların yarsından fazlası tezgahlarının kimyasal maddelere karşı dayanıklı olduğu konusuna katılmaktadır. Tezgah malzemesi olarak laminant kaplama ve werzalit kullanan kullanıcıların yarısı ise bu duruma katılmamaktadır (Şekil 6).

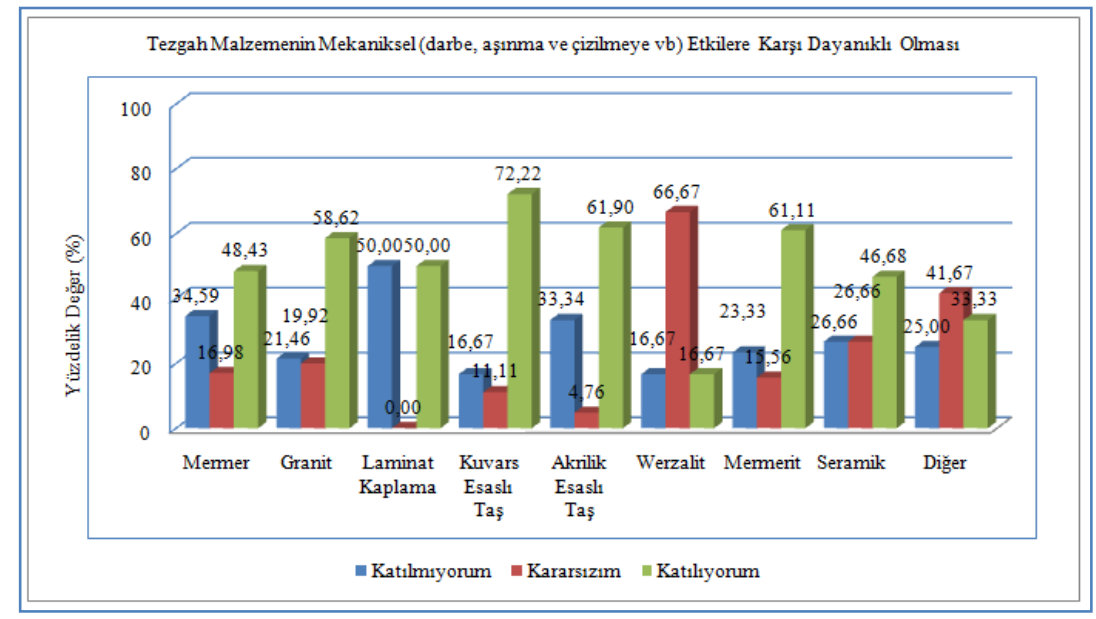

Şekil 7. Tezgâh Malzemesinin Mekaniksel Etkilere Karşı Dayanıklı Olması Nedeniyle Tercih Edilmesi.

Şekil 7 incelendiğinde tezgahlarında kuvars esaslı taş, werzalit, akrilik esaslı taş, mermerit ve granit malzeme kullanan kullanıcıların yarısından fazlası tezgahlarının mekaniksel (darbe, aşınma ve çizilmeye vb) karşı dayanıklı dayanıklı olduğuna katılmaktadır. Tezgahında werzalit bulunan kullanıcılar ise bu duruma katılmamaktadırlar. 


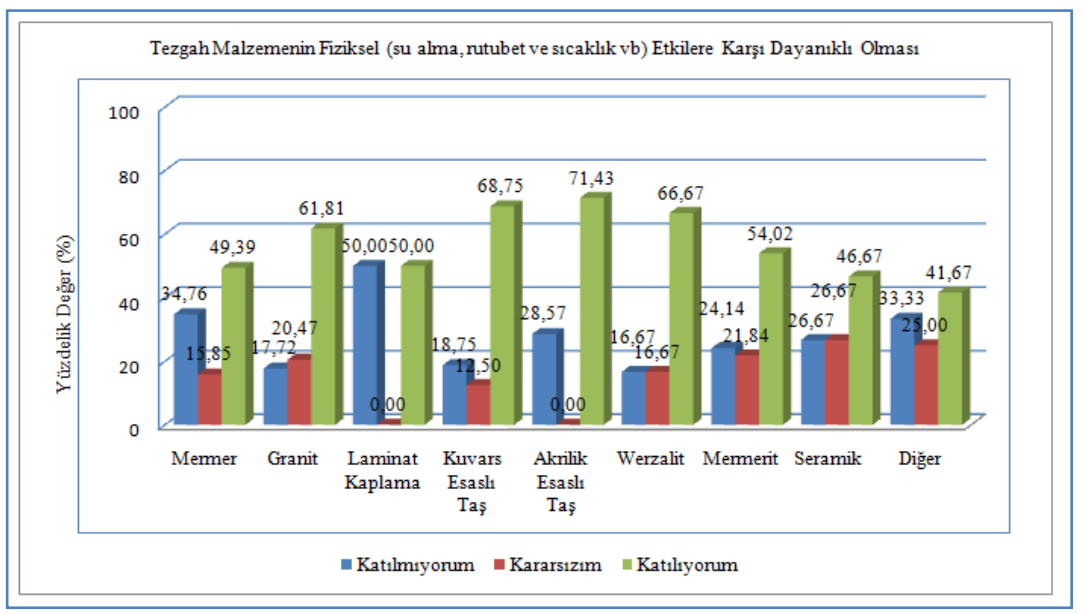

Şekil 8. Tezgâh Malzemesinin Fiziksel Etkilere Karşı Dayanıklı Olması Nedeniyle Tercih edilmesi.

Yapılan araştırmaya göre akrilik esaslı taş, kuvars esaslı taş, werzalit, granit ve mermerit kullanan kullanıcıların yarısından fazlası bu malzemeleri fiziksel (su alma, rutubet, sıcaklığa vb) karşı dayanıklı olduğu konusuna katılmaktadır. Tezgah malzemesi olarak laminant kaplama kullanıcıların yarısı ise bu duruma katılmamaktadır (Şekil 8).

\section{SONUÇLAR ve TARTIŞMA}

$\mathrm{Bu}$ çalışmada; kullanıcının aradığı nitelikleri taşıyan tezgâh malzemeleri mutfakta geçen zamanın verimli bir biçimde kullanılmasına olanak sağlamanın yanı sıra kullanıcının psikolojik olarak da yapılan işe konsantre olmasına destekleyici bir durum oluşturmaktadır. Bu düşünce kapsamında yapılan çalışma sonucunda, mutfak mekânında sabit donatı elemanlarından biri olarak kullanılan tezgâh malzemeleri için kullanıcı tercihleri incelenmiş ve aşağıdaki sonuçlara varılmıştır.

Sonuçlara göre; mutfak tezgâh malzemelerin çeşitliliği ve kullanım yaygınlığı bakımından incelendiğinde, kullanıcıların en çok granit, mermer ve mermerit, en az ise laminant kaplama, werzalit, akrilik, kuvars esaslı taş ve seramik malzemeleri kullandıkları görülmektedir.

Mutfak mekânında kullanılan tezgâh malzemelerinin kullanıcı tercihleri açısından incelenmesi adlı çalışmada; tezgah çeşitliliği ve kullanım yaygınlığı bakımından tezgahta en çok kullanılan malzemenin mermer ve granit olduğu ayrıca laminant kaplama, werzalit, mermerit, akrilik ve kuvars esaslı taş gibi tezgah malzemeleri kullanıcılar tarafından az bilinen ve kullanımı az olan malzemeler olduğu belirtilmiştir(Tavşan ve Küçük, 2013).

Gelir düzeyi bağlamında tezgah malzeme kullanımı incelendiğinde ,toplam aylık gelir düzeyi 2000 TL'den düşük olan kullanıcıların werzalit ve seramik; toplam aylık geliri 2001-4100 olan kullanıcıların mermerit ve laminant kaplama; ancak toplam aylık geliri 4101TL den fazla olan kullanıcıların ise, akrilik esaslı taş ve mermerit 
kullanımı yoğunlaşmaktadır. Ekolojik, kimyasal maddelere, mekaniksel ve fiziksel etkilere karşı dayanıklı bir malzeme olduklarını düşündükleri için kullanmaktadırlar.

Gelir düzeyi bağlamında tezgah malzeme kullanımı incelendiğinde, gelir düzeyi 2000 TL'ye kadar mermer kullanımı yoğunken; gelir düzeyi artmaya başladıkça benzer oranlarda mermer ve granit kullanılmakta ancak, gelir düzeyi en üst seviyeye yaklaştıkça granit kullanımı yoğunlaşmaktadır (Tavşan ve Küçük, 2013).

Konut yaşlarına göre tezgâh malzeme türü kullanımına bakıldığında, konut yaşı 0-5 yıl olan kullanıcıların kuvars esaslı taş, granit ve mermer: konut yaşı 5-10 yıl olan kullanıcıların seramik, laminant kaplama, werzalit ve mermerit: komut yaşı 10-15 yıl olan kullanıcıların laminant kaplama: konut yaşı 15 yıl üstü olan kullanıcıların ise seramik, malzemesi kullandıkları görülmektedir. Yeni konutlardaki kullanıcıların; daha çok kuvars esaslı taş, granit ve mermer kullandıkları ve bu tezgahları ekolojik, kimyasal maddelere, mekaniksel ve fiziksel etkilere karşı dayanıklı bir malzeme olması nedeniyle tercih ettikleri görülmektedir.

Tezgâh malzemeleri kullanan kullanıcıların tercih etme sebepleri ile ilgili olarak yapılan çalışmada, tezgâh malzemelerinden laminat kaplama, werzalit, mermer, kuvars esaslı taş, mermerit ve seramiğin ekonomik olması: tezgâh malzemelerinden werzalit ve kuvars esaslı taşın ekolojik (çevreyle ilgili) olması: tezgâh malzemelerinden kuvars esaslı taş, akrilik esaslı taş, seramik, mermer granit ve mermeritin kimyasal maddelere karşı dayanıklı olması: tezgâh malzemelerinden kuvars esaslı taş, werzalit, akrilik esaslı taş, mermerit ve granitin mekaniksel (darbe, aşınma ve çizilmeye vb) etkilere karşı dayanıklı olması: tezgâh malzemelerinden akrilik esaslı taş, kuvars esaslı taş, werzalit, granit ve mermeritin fiziksel (su alma, rutubet, sıcaklığa vb) etkilere karşı dayanıklı olması nedeniyle tercih ettikleri görülmektedir.

Yapılan araştırmada tezgah malzemelerinden granit, kuvars esaslı taş, mermer ve mermeritin çizilmeye karşı dayanıklı olduğu; granit, seramik, mermer, kuvars esaslı taş ve mermeritin ısıya karşı dayanıklı olduğu ve laminant kaplamanın hiç dayanıklı olmadığı; akrilik esaslı taş, seramik, granit, mermer, mermerit ve kuvars esaslı taşın kimyasallara karşı dayanıklı olup, laminant kaplamanın hiç dayanıklı olmadı̆̆ı; seramik, granit ve kuvars esaslı taşın sert ve sivri cisimlerin darbelerine dayanıklı olup, laminant kaplama ve mermeritin dayanıklı olmadığı; mermerit, akrilik esaslı taş, granit ve kuvars esaslı taşın su birikintilerine karşı kabarmadığı; mermerit, granit, akrilik ve kuvars esaslı taşın kire karşı dayanıklı olduğu; olduğu; mermer, granit, laminant kaplama, werzalit, mermerit, akrilik ve kuvars esaslı taşın kolay temizlendiği gibi nedenlerle kullanıldığı belirtilmiştir (Tavşan ve Küçük, 2013).

Mutfakların bazılarında kullanılan laminant tezgahların birleşim yerlerinin konstrüksiyonu ve damlalık kısmı ve tezgah üzerine evye, batarya ve set üstü ocak için açılan boşluklar, tezgah ile ekipmanların bağlantı kısımlarındaki yalıtım malzemeleri uygun seçilmediği ve özenli işçilik yapılmadığından bu kısımların içersinde su alarak şekil değiştirmektedir. Tezgah malzemenin, bu faktörler dikkate alınarak tercih edilmesini belirtmiştir (Yıldırım, 1999). 
Yapılan araştırmada tezgah malzemelerinden laminant tezgahın çizilmeye, ısıya, kimyasallara, sert ve sivri cisimlerin darbelerine karşı hiç dayanıklı olmadığı belirtilmiştir (Tavşan ve Küçük, 2013).

Tezgah malzemesi olarak kullanılan mermerler, çoğunlukla kolay çizilmesi ve lekelenmesi nedeniyle istenmemektedir. Yeniden yapılan tezgahlar hem doğal kaynakların tükenmesine neden olurken hem de ekonomik açıdan tüketiciye fazla yük getirecektir.yeni yapılan konutlarda çoğunlukla laminant kaplamalı malzemeler tezgah malzemesi olarak kullanıldığını belirtmiştir (İlçe, 2001).

$\mathrm{Bu}$ araştırma kapsamında elde edilen veriler ve sonuçlar gelecekte gerçekleştirilecek olan çalışmalar için yardımcı niteliktedir. Çalışmanın sonucuna bağlı olarak, gün geçtikçe artan malzeme çeşitlerinin kullanıcılar tarafından az bilindiği ortaya çıkmaktadır. Bu durumu ortadan kaldırmak için reklam ya da bilgilendirme toplantıları düzenleyerek değişen ve gelişen malzemeler hakkında bilgi verilebilir.

Elde edilen veriler sonucunda kullanım çeşitliliği ve tercih edilme sebebine bağlı olarak ilgili birimler tarafından mutfak tezgahı olarak, ekonomik, ekolojik (çevreyle ilgili), kimyasal maddelere, mekaniksel ve fiziksel etkilere karşı dayanıklı bir tezgah malzemesi olarak kuvars esaslı taş üretimi gerçekleştirmenin yararlı olabileceği anlaşılmaktadır. Özellikle son zamanlarda yaygınlaşan hazır mutfakların kullanımının artırılması için benimsenen tezgâh malzemelerin geliştirilmesi mobilya endüstrisine katkı sağlayacaktır.

Elde edilen veriler sonucunda mutfak tezgahı olarak, aşınma payı çok düşük, leke tutmayan, kolay temizlenebilen, 1sı ve darbe gibi fiziksel etkilerden ve kimyasal maddelerden etkilenmeyen, bir tezgah malzemesi üretimi gerçekleştirmenin yararlı olabileceği anlaşılmaktadır.

Uşak il merkezi kentsel yerleşim alanını oluşturan farklı sosyo-ekonomik düzeylere sahip ailelerini (Alt/Orta/Üst/SED) kapsayacak şekilde yapılacak anket çalışması sonuçları ile bu çalışmanın sonuçlar karşılaştırılabilir.

\section{KAYNAKÇA}

Akgül, F. (2008). http://www.sabittuncel.com/main.php?kid=5 95, 15 Aralık 2008.

Anonim, (2007a). Tezgâhlarınızı Giydiren Şıklık, Banyo+Mutfak Dergisi, 55, 182-189.

Anonim, (2007b). En İyi 10 Mutfak Tezgâhı, Evim Dergisi, 4,115.

Dellaloğlu, B. (2002). Konut Mutfaklarında Kullanılan Tezgâhların Fiziksel, Mekaniksel ve Teknolojik Özelliklerinin Belirlenmesi, Yüksek Lisans Tezi, Hacettepe Üniversitesi, Fen Bilimleri Enstitüsü, Ankara.

Efendioğlu, S. (2001). Geçmişten Günümüze Konutta Mutfak Kavramı: Açık Mutfak, Yüksek Lisans Tezi, Karadeniz Teknik Üniversitesi, Fen Bilimleri Enstitüsü, Trabzon.

Gürleyen, L. (2005). Kutu Mobilya ve Masif Sandalye Üretiminde Fabrika Planlama Sorunları ve Çözüm Önerileri, Doktora Tezi, Gazi Üniversitesi, Fen Bilimleri Enstitüsü, Ankara.

Hasol, D. (2002). Ansiklopedik Mimarlık Sözlüğü, 8. Baskı, Yem Yayın, İstanbul. 
İlçe, A. C. (2001). Konut Mutfağı Fiziksel Çevre Düzenlenmesinde Alan Boyutu ve Birey Sosyo-Kültürel Yapısının Mutfak Mobilyası Tasarımına Etkileri, Yüksek Lisans Tezi, Hacettepe Üniversitesi, Fen Bilimleri Enstitüsü, Ankara.

Işık, Z. (1992). Geleneksel ve Günümüz Evlerinin İç Mekân Analizi, Gazi Üniversitesi, Fen Bilimleri Enstitüsü, Doktora Tezi, Ankara.

İmamoğlu, V. (1986). Ankara'da Alt Sosyo-Ekonomik Düzey Ailerinin Konutları ve Yaşam Biçimleri; ODTÜ Mimarlık Fakültesi Dergisi. Cilt 8/1, Ankara.

Kalınkara, V. (1990). Yaşlı Kadınlarda Antropometrik Veri-Mutfak Donanımı İlişkisi Üzerine Bir Araştırma, Doktora Tezi, Ankara Üniversitesi, Fen Bilimleri. Enstitüsü, Ankara.

Küreli, İ. (1996). Yongalevha ve Lif Levhaların Islak Mekânlarda Kullanma İmkânları Üzerine Araştırmalar, Gazi Üniversitesi, Fen Bilimleri Enstitüsü, Doktora Tezi, Ankara.

Nemli, G. (2000). Yüzey Kaplama Malzemeleri ve Uygulama Parametrelerinin Yonga Levha Teknik Özellikleri Üzerine Etkileri, Doktora Tezi, KTÜ, Fen Bilimleri Enstitüsü, Trabzon.

Söğütlü, C. (1998). Konut Mutfak Tezgahlarında Malzemelerin Mekanik Etkilere Karşı Performanslarının Karşılaştırılması, Gazi Üniversitesi, Fen Bilimleri Enstitüsü, Doktora Tezi, Ankara.

Sözer, S. (1990). Konut Mutfaklarında Söz Konusu Eylemler, Bu eylemlere Yönelik Kullanıcı Gereksinmeleri ve İç Donatım Elemanları, Yüksek Lisans Tezi, Hacettepe Üniversitesi, Sosyal Bilimler Enstitüsü, Ankara.

Tavşan, F. ve Küçük, P. (2013). Mutfak Mekânındaki Sabit Donatı Yüzeylerinde Kullanılan Malzemelerin Tespiti: Trabzon Örneği, 6. Ulusal Yapı Malzemeleri Kongresi, 7-9 Kasım, İstanbul.

URL-2, http://tr.wikipedia.org/wiki/Granit. 01 Nisan 2013.

URL-3,http://www.serki.com/index.php?bolumsec=terimler\&id=t66rraSeramik. 01 04.2013.

URL-4,http://www.dekorguru.com/2011/05/yapay-tas-tezgâh-ustu malzemesi.html Yapay Taş. 01.04.2013.

URL5,http://corian.com.tr/Corian/tr_TR/assets/downloads/documentation/Corian_nedir_tr.pdf Akrilik Esash Yüzey Malzemesi. 1 Nisan 2013.

Yeşilkavak, F. (2006). Apartman Konut Mutfaklarında İç Mekân Tasarımının Kullanıcı Memnuniyetine Etkileri, Yüksek Lisans Tezi, Gazi Üniversitesi, Fen Bilimleri Enstitüsü, Ankara.

Yıldırım, K. (1999). Konut Mutfaklarının Mekân ve Donatı Organizasyonunda Ergonomik Yaklaşım, Doktora Tezi, G.Ü. Fen. Bil. Enst., 242-248, Ankara.

Zorlu, T. (1996). Trabzon Kent Ölçeğinde Kullanıcı Gereksinmelerine Bağlı Olarak Mutfak Mekânı ve Tipleri Üzerine Bir Araştırma, Yüksek Lisans Tezi, Karadeniz Teknik Üniversitesi, Fen Bilimleri Enstitüsü, Trabzon 